\title{
Does CO2 and Its Possible Determinants are Playing Their Role in the Environmental Degradation in Turkey. Environment Kuznets Curve Does Exist in Turkey.
}

\author{
${ }^{1}$ Zia Ur RAHMAN \\ 1. First Author Preston University, Kohat, KPP, Pakistan. Email: zia4939@ gmail.com
}

Received: December 08, 2019. Revised: December 08, 2019. Accepted: December 08

\begin{abstract}
Over the last few decades, the atmospheric carbon dioxide emission has been amplified to a great extent in Turkey. This amplification may cause global warming, climate change and environmental degradation in Turkey. Consequently, ecological condition and human life may suffer in the near future from these indicated threats. Therefore, an attempt was made to test the relationship among a number of expected factors and carbon dioxide emissions in the case of Turkey. The study covers the time series data over the period of 1970-2017. We employed the modern econometric techniques such as Johansen co-integration, ARDL bound testing approach and the block exogeneity. The results of the Johansen co-integration test show that there is a significant long-run relationship between carbon dioxide emissions and expected factors. The long-run elasticities of the ARDL model show that a $1 \%$ increase in the GDP per capita, electric consumption, fiscal development and trade openness will increase carbon dioxide emissions by $0.14,0.52,0.09$ and $0.20 \%$ respectively. Further, our findings reveal that the environmental Kuznets curve (EKC) hypothesis and inverted U-shaped relationship between carbon dioxide emission and economic growth prevails. Therefore, the EKC hypothesis is valid and prevailing in the Turkish economy. The diagnostic test results show that the parameters of the ARDL model are credible, sTable and reliable in the current form. Finally, Block exogeneity analysis displays that all the expected factors are contributing significantly to carbon dioxide emissions in the Turkish economy.
\end{abstract}

Keywords: Environmental Degradation, CO2, ARDL JEL Classifications: Q52

\section{Introduction}

A Worldwide challenging issue now a day is the ecological depletion and greenhouse gasses which is attaining an acute form due to rapid industrialization, urbanization and the agricultural eradication (Kijima et al., 2010). Currently, weather change is the fundamental subject matter of the modern age and have financial, traditional and the environmental influence on the economy. So, the technical enhancement (industrialization), combustion of the fossil fuels has amplified the carbon dioxide emission which is the main reason of the global warming and environment degradation globally (Nasir \& Rehman, 2011; Gamage \& Kuruppuge, 2017). In the early stages of the 1990 's, to illustrate the income and the environmental reduction, environmental Kuznets curve (EKC) hypothesis were introduced to explain the affiliation between them (Gill et al., 2017). Scientific research elaborates that global warming and the climate change is due to the greenhouse gasses (GHG) (Abas \& Khan 2014; Karl \& Trenberth 2003; Ramachandra et al., 2015; Li \& Yang, 2016; Fereidouni, 2013). A number of studies revealed that greenhouse gasses are the combination of methane, nitrous oxide, water vapor, carbon dioxide and ozone. And found that carbon dioxide is the key element of the GHG and the main cause of the environmental change globally (Ullah et al., 2018). 
It is analyzed that as compared to the 1990 the emission of the carbon dioxide in 2014 is higher about the $42 \%$, meaning that the carbon emission in the environment has been increased to the substantial level (Aung et al., 2017). Intergovernmental Panel on Climate (2013) reported that the major reason behind the increase in the temperature of the earth is the mainly the carbon dioxide. It is also investigating that the key element of the pollution approximately $60 \%$ GHG accompanied with the other factors (Baek and Pride 2014).

Moreover, the emerging economies are under the strong influence of achieving the development along with the socioeconomic objectives along with the cherish environment. However, it is considered that the important point of the growth-environment nexus is the technical enhancement (industrialization) which in turn increases the $\mathrm{CO} 2$ emission, but with the passage of time while attaining the economic growth than reduction in the CO2 initiated due to installing the environmentally friendly technologies (Dinda, 2004; Marsiglio et al., 2016; Sharma, 2011; Sinha \& Bhatt, 2017).

According to the World Energy Outlook 2014, about 50\% of the world GDP are carried by the developing economies and supposed to be increased about $60 \%$ in the 2030. It is supposed that trade openness is the reason behind the economic development, under the consideration of various socioeconomic policy reforms, the most convincing factor of emission is the trade openness (Ling, Ahmed, Muhamad \& Shahbaz, 2015). While the links and benefits of trade openness are the well recognize and strong affiliation back to the Adam Smith's Comparative Advantage theory and the emerging economies with the context of beneficiaries of the trade openness (Edwards, 1992).

Now a day world economy is transmitted into the inorganic economy, it is reported the reason of the global warming based on the climate change, the unexpected and the deteriorating environment circumstances are the threat which world is facing today. The air-water pollution, soil eradication, rise in temperature and irregular rain patterns are the singing of the environmental depletion and the degradation are generally affiliated with the industrialization (Ahmad, Shahbaz \& Qasim, 2015; NASA, 2015). According to the World Bank (2013), it is the preindustrial era which almost increase the world temperature about $4 \%$. They further illustrate that marine ecosystem, sea-level rise, extreme heat waves and the water are all at stake in the near future.

It is reported and noted that energy is the blood in the modern industry and non-industrial sectors and the major source of emission, globally it is observed that the energy consumption has been double since 1950 as well as CO2 per capita is also double. It is reported that no doubt industrialization is increasing, however, to fill the demand energy consumption is also increased which not only produces greenhouse gases, but also reduces the volume of nonrenewable resources. With high utilization of the energy and the fossil fuel the developing economies are largely compromising the ecosystem (Shahbaz, Ozturk \& Afza, 2013).

However, the EKC hypothesis suggests that at early stages of the fiscal, economic development, industrialization and urbanization, the natural resources are depleted. Here economic growth and the pollution are positively affiliated. And with the passage of time, urbanization and the industrialization remain, which assist to develop the environment friendly techniques to reduce the pollution (Panayotou, 1993).

While globalization is the wide terminology which is comprised on the economic, political and social dimensions. And the capital flows, investment, trade liberalization, economic growth and technological change are the key factors of economic globalization (Torres 2001). However, a little evidence is available which support the argument that globalization affects all the economies on a same level (Antweiler et al., 2001). So, globalization, speed up the structural change in the industry because the demand of the foreign products. That's why globalization boosts up the investment and the flow of technologies. Which in turn enhances the international trade, total factor productivity, which smooths the way for the foreign direct investment mobilization of the latest technologies from developed to developing countries. The globalization enhanced the growing anxieties and may cause the environmental degradation. Additionally, creates environmental issues such as global warming, depletion of the ozone layer, loss of biodiversity, depletion of natural resources and widespread deforestation (Shahbaz et al., 2017a). Moreover, numerous researchers' illiterates that globalization has the effect of the environmental degradation (Dean 2002; Copeland \& Taylor, 1995; McAusland, 2008; Frankel 2009). Moreover, Shahbaz et al. (2013c) explores that globalization has significant influence on the environmental degradation in the existence of the EKC hypothesis

However, numerous studies indicated that economic growth, energy consumption and the $\mathrm{CO} 2$ emissions have various miscellaneous outcomes so there is a need for more research to elaborate the nexus between them. Recently, research has been conducted to capture the affiliation between them with a variety of econometric techniques i.e. Ordinary least squares (OLS), error correction model (ECM) for long run and short run impacts; the vector error correction model (VECM) and Granger causality (GC) approach for causal relationship; innovative accounting approach (IAA) to examine the strength of causality analysis and the co-integration for long term in the presence of structural breaks among the variables (Apergis \& Payne, 2009; Baranzini, Weber, Bareit, \& Mathys, 2013; 
Charfeddine \& Ben khediri, 2015; Chen, Kuo \& Chen, 2007; Ghosh, 2010; Omri, 2013; Wolde-Rufael, 2005; Yuan, Zhao, Yu \& Hu, 2007).

Financial development degrades the environmental two ways, firstly the utilization of energy can be very high due to utilization of the high technology and secondly for the safety of the environment, the protection law can be ratified with increased funding and decreased costs (Tamazian et al., 2009). So, the depletion can be reduced in the environment by the financial development. Although, amplified investment, reduction in the cost and the energy utilization generated by the financial development smooth the way for growth (Dasgupta et al., 2001). However, this type of product has the negative influence on the environment.

The urbanization enhanced the energy utilization along with the more depletion of natural resources, is the indication of high rate $\mathrm{CO} 2$ emissions. IRENA, 2016 reported that the cities whom energy consumption is about the two thirds of global energy, are generating the $70 \%$ energy-related $\mathrm{CO} 2$. Additionally, $32.8 \%$ and $121.5 \% \mathrm{CO} 2$ are emitted by the oil and coal fuels in Turkey in-between 1990 to 2104 (IEA, 2016). However, about 16,850,822 kt of CO2 added to the atmosphere in 1974, which has been doubled $(36,138,285 \mathrm{kt})$ in 2014 . Meanwhile, in Turkey $466 \%$ carbon emission has been increased as compared to the 0.36 percent in 1974 and 0.96 percent in 2014 globally (World Bank, 2018).

Numerous research work investigated and reported that EKC hypothesis in the context of energy consumption increased carbon dioxide emissions. Seker et al. (2015), Ozatac et al. (2017), Pata (2018) for Turkey; Saboori \& Sulaiman (2013) for Malaysia; Ozturk \& Al-Mulali (2015) for Cambodia; Kanjilal \& Ghosh (2013) for India; Nasir \& Rehman (2011), Javid \& Sharif (2016) for Pakistan; Rafindadi (2016) for Japan and Riti et al. (2017) for China. However, the urbanization may be depleting the environment positively or the negative. Due to urbanization the energy utilization has been increased and the carbon emission as well (Zhang, 2012; Wang et al., 2016; Zhang et al., 2017) while utilizing the panel research for the countries like Brazil, Indonesia, China and India. Although Alam et al, 2016 finding illustrates a significant association between an increase in the population of Brazil and India and carbon emission and was insignificant in the case of the Indonesia and China for the short and the long-time span.

Moreover, numerous researches have been made to establish an association among urbanization, energy consumption, economic growth and carbon emissions within a country. For example, in the China, Wang et al. (2017), in the east region urbanization has no significant effect in the carbon emission where is the most urbanization in the china while in the west region, it was found that urbanization positively influence the $\mathrm{CO} 2$ emission.

While Shahbaz et al. (2014) reported that in UAE urbanization, electricity consumption, economic growth and carbon emissions are co-integrated in the long term, employing the bound test accompanied with the structural break. This study also revealed that energy utilization and the $\mathrm{CO} 2$ negatively associated while urbanization positively influence the CO2. Meanwhile, Katircioglu \& Katircioglu (2017) for the Turkish economy, it was reported that due to rapid urbanization, increase the energy utilization which in turn positively affiliation with the $\mathrm{CO} 2$ emission in the economy.

Currently, numerous studies intensively gave attention to determine the association among the economic growth, globalization, energy consumption, financial development, globalization and the $\mathrm{CO} 2$ emission. In this scenario Shahbaz et al. (2017b) for the Japan conduct a study to capture the influence of the globalization on the CO2 emission along with the energy consumption and the economic growth utilizing the data from 1970-2014 employing the NRDL model and reported that energy consumption, globalization and economic growth increase $\mathrm{CO} 2$ emissions. However, Shahbaz et al. (2017a) found in the case of China, globalization along with sub-indexes in the existence of EKC reduce the CO2 emission while utilizing the data from 1970-2012. And same results were found in the case of Turkey (Shahbaz et al., 2013c)

Moreover, Shahbaz et al. (2016) conducted a study in 19 African countries over the period 1971-2012 while utilizing the ARDL technique to capture the effect of the globalization and power consumption on the $\mathrm{CO} 2$ emission and found miscellaneous results in the research. And further reported that EKC hypothesis prevails in the Algeria, Cameroon, Congo Republic, Morocco, Tunisia and Zambia. Furthermore, Shahbaz et al. (2017c) in the perspective 25 developed economies while utilizing the time series and the panel data techniques and found that globalization increases the $\mathrm{CO} 2$ emission.

For the BRICS countries (Brazil, China, India, Russia, and South Africa) Haseeb et al. (2018) conducted a study and found that globalization decline the $\mathrm{CO} 2$ emission in the presence of the EKC hypothesis, while utilizing the energy consumption, financial development, globalization, economic growth, and urbanization.

The core objective of the study is to investigate the existence of the EKC in the Turkish economy either it is depleting its environment like others or at the edge of the destruction. For this purpose, this work employs all the possible determinant (GDP per capita, energy consumption, financial development, trade openness, urbanization and the overall globalization) of the $\mathrm{CO} 2$ emission which are present and silently depleting the environment. This study 
will expand the current literature by using the structural break is the data and employing the ARDL technique to determine the short as well as long term affiliation among the possible determinants of the $\mathrm{CO} 2$ emission, along with numerous diagnoses, co-efficient and the stability tests and also utilize the VAR for the dynamicity of the factors in the coming time frame.

\section{Data and Methodology}

Brantley Liddle (2014) reported that there are factors which are influenced by the increase in the level of population such as carbon emission, GDP per capita, urbanization and the energy utilization. However, this study will employ the Cobb-Douglas model to investigate the affiliation among the Carbon emission and the expected elements which are GDP per capita, energy consumption, financial development, urbanization, trade openness and the overall globalization (Imran et al., 2019).

Many encouraging features are attached with the Cobb-Douglas functions so many research works employed the said technique (Hossain, 2011; Farhani \& Ozturk, 2015; Farhani et al., 2014; Shahbaz \& Lean, 2012; Sharma, 2011), for instant numerous inputs and the calculations can handle with ease. It also can detect and express the response of the factors in elasticity, non-linear equation can be expressed such as.

$$
\mathrm{C}=\mathrm{f}\left(\mathrm{Y}^{\alpha 1} \text { Engy }^{\alpha 2} \mathrm{Fdeve}^{\alpha 3} \operatorname{Trade}^{\alpha 4} \mathrm{Ubz}^{\alpha .5} \mathrm{Gliz}^{\alpha 6} \eta^{\varepsilon}\right)
$$

Where $\mathrm{C}$ is the carbon emission and $\mathrm{Y}$, Engy, Ubz, Trade, and Fdeve stand for the GDP per capita, energy consumption, urbanization, trade openness and financial development, respectively. While A and $\mu$ represent the technical and error terms. And $\alpha 1 \ldots \alpha 6$ are the constant returns to scale (CRS) linked with the expressed variables. By taking the log of all the factors then the old model replaced with the log model which means that parameters will measure the responsiveness of $\mathrm{CO}_{2}$ emissions with all the factors in elasticity. The linear model is given as below.

$$
\begin{aligned}
& \text { 1n } \mathrm{C}_{\mathrm{t}}=1 \mathrm{nA}+\alpha^{1} \ln \mathrm{Y}_{\mathrm{t}}+\alpha^{2} \operatorname{lnEngy}_{\mathrm{t}}+\alpha^{3} \text { nnFdeve }_{\mathrm{t}}+\alpha^{4} \text { 1nTrade }_{\mathrm{t}} \\
& +\alpha^{5} 1 \mathrm{nUbz}_{\mathrm{t}}+\alpha^{5} \operatorname{lnGliz}_{\mathrm{t}}+\eta_{\mathrm{t}} \\
& \text { Replaced } \ln \mathrm{A}=\alpha_{0} \\
& \text { 1n } \mathrm{C}_{\mathrm{t}}=\alpha_{0}+\alpha^{1} \ln \mathrm{Y}_{\mathrm{t}}+\alpha^{2} \operatorname{lnEngy}_{\mathrm{t}}+\alpha^{3} \operatorname{lnFdeve}_{\mathrm{t}}+\alpha^{4} 1 \text { nTrade }_{\mathrm{t}} \\
& +\alpha^{5} 1 \mathrm{nUbz}_{\mathrm{t}}+\alpha^{6} 1 \mathrm{nGliz}_{\mathrm{t}}+\eta_{\mathrm{t}}
\end{aligned}
$$

Where $\ln \mathrm{C}_{\mathrm{t}}, \ln \mathrm{Y}_{\mathrm{t}}, \ln \mathrm{Engy}_{\mathrm{t}}, \operatorname{lnFdeve} \mathrm{e}_{\mathrm{t}}, \ln$ Trade $_{t}, \ln \mathrm{Ubz}$ and in Gliz are the natural logarithm of carbon emissions measured as $\mathrm{CO}_{2}$ metric tons per capita, real GDP per capita in constant 2010 US\$, energy consumption is measured as energy use in $\mathrm{kg}$ of oil equivalent per capita, urbanization as urban population (\% of total), trade openness as exports and imports of goods and services (\% of GDP), and financial development as domestic credit to the private sector (\% of GDP), respectively. While $\eta_{t}$ is the error term and supposed to be normally distributed. All data set was taken from the World Bank Development Indicators (WDI 2018) for the periods 1970 to 2017. However, to investigate the existence of the EKC hypothesis in the Turkish economy, a number of varying variables were employed while re-arranging the environmental equation as energy consumption, financial development, urbanization, trade openness and the overall globalization.

$$
\begin{aligned}
1 \mathrm{nC}_{\mathrm{t}} & =\alpha_{0}+\alpha_{1} \operatorname{lnY}_{\mathrm{t}}+\alpha_{2} \operatorname{lnY}_{\mathrm{t}}^{2}+\alpha_{3} \operatorname{lnEngy}_{\mathrm{t}}+\alpha_{4} \operatorname{lnFdeve}_{\mathrm{t}}+\alpha_{5} \text { 1nTrade }_{\mathrm{t}} \\
& +\alpha_{6} 1 \mathrm{nUbz}_{\mathrm{t}}+\alpha_{6} \operatorname{lnGliz}_{\mathrm{t}}+\eta_{\mathrm{t}}
\end{aligned}
$$

However, $\mathrm{t}$ stand for time trend, $\alpha_{0}$ shows the fix effect and the $\eta_{t}$ denotes the random error, moreover $\alpha_{1} \ldots \alpha_{6}$ explains the long-term elastics of all variables. While in the perspective of the EKC approach the coefficients of the parameters like $\alpha 1$ and $\alpha 2$ should be positive and negative correspondingly.

A number of studies such as Yavuz (2014), Heidari et al. (2015), Seker (2016), Jamel \& Maktouf (2017) and besides with other work, define the association in the context of $\mathrm{CO}_{2}$ productivity and the income and provides a lot of evidence for the cogency of the EKC approach in many different regions of many countries across the world. While numerous researchers found (Arouri et al., 2012; Normee Che Sab, 2013; Onafowora \& Owoye, 2014; 
Ziabakhsh-Ganji, 2015) that the magnitude of the $\alpha_{3}$ should be positive because when economic growth increases, it will increase the utilization of the energy which in turn enhance the $\mathrm{CO}_{2}$ productivity in the economy.

However Alam et al. (2007), Nguyen et al. (2017), Pata (2018) thinks off that the parameter $\alpha_{4}$ vary from country to country which based on the economic development or the panel of countries. They further illustrate that due to urbanization, utilization of energy increased which promotes the production of $\mathrm{CO}_{2}$. On the contrary, urbanization enhances the economic growth with the accumulation of the environment friendly techniques and efficiency in the production, which in turn reduce the level of surroundings depletion (Ogebe, 2017; Chen et al., 2017; Han et al., 2017).

Moreover, the effect of the $\alpha_{5}$ depends on the growing stage, which economy is passing, it is considered negative for the developed nation because they purchase the goods which affects the environment from other countries where the environmental protection laws are not restricted followed (NjindanIyke \& Ho, 2017; Zhang et al., 2017, 2018; OH \& Bhuyan, 2018). While in the growing economies the sign is positive because they are increasing their production without considering/following the cautions rule and regulation to protect the surroundings. That' why developing nation has the greatest share in the depletion of the surroundings so the trade openness level is high with a great addition of $\mathrm{CO}_{2}$ in environ (Boutabba, 2014; Farhani \& Ozturk, 2015; Bombardini \& Li, 2016; Shahzad et al., 2017; Ali et al., 2018).

Under the consideration of the previous work, it's the need of time to develop the widespread methodology to capture the expected conceivable factors of carbon emission in the economy. This study will employ the time series data and the pre- requisite for the time series i.e. Data should be stationery for this purpose, conventional unit root test for instance ADF test and PP test were employed, but this study also employed the Zivot-Andrew (ZA) test also known as the structural break test.

$$
\begin{gathered}
\Delta Y_{t}=\alpha Y_{t-1}+\sum_{i=1}^{n} \alpha \Delta Y_{t}+\mu_{t} \\
\Delta \mathrm{Y}_{\mathrm{t}}=\lambda_{0}+\lambda_{1} \mathrm{Y}_{\mathrm{t}-1}+\sum_{\mathrm{i}=1}^{\mathrm{n}} \lambda \Delta \mathrm{Y}_{\mathrm{t}}+\mu_{\mathrm{t}} \\
\Delta \mathrm{Y}_{\mathrm{t}}=\lambda_{0}+\lambda_{1} \mathrm{Y}_{\mathrm{t}-1}+\sum_{\mathrm{i}=1}^{\mathrm{n}} \lambda \Delta \mathrm{Y}_{\mathrm{t}}+\lambda_{2} \mathrm{~T}_{\mathrm{t}}+\mu_{\mathrm{t}}
\end{gathered}
$$

The PP test can be expressed like.

$$
\Delta \mathrm{Z}_{\mathrm{t}}=\beta \mathrm{A}_{\mathrm{t}}+\pi \mathrm{Z}_{\mathrm{t}-1}+\mu_{\mathrm{t}}
$$

Although, Perron says that if there is a structural break in the data, then the influence remains in the series in the beginning this effect is transitory with the passage of time become permanent, then Zivot and Andrew (1992) introduce the revolutionary idea, while introducing the sequential trend break model to detect the endogenous break with the assistance of the following models. Model A and model B allow for a change in the intercept and in the slope, respectively, while model $\mathrm{C}$ allows for a change in both intercept and slope.

Model A

$$
\Delta \mathrm{S}_{\mathrm{t}}=\eta+\beta \mathrm{S}_{\mathrm{t}-1}+\beta_{\mathrm{t}}+\varphi \mathrm{DU}_{\mathrm{t}}+\sum_{\mathrm{k}=1}^{\mathrm{h}} \mathrm{b}_{\mathrm{j}} \Delta \mathrm{S}_{\mathrm{t}-\mathrm{k}}+\mu_{\mathrm{t}}
$$

Model B

$$
\Delta \mathrm{S}_{\mathrm{t}}=\eta+\beta \mathrm{S}_{\mathrm{t}-1}+\beta_{\mathrm{t}}+\lambda \mathrm{DT}_{\mathrm{t}}^{*}+\sum_{\mathrm{k}=1}^{\mathrm{h}} \mathrm{b}_{\mathrm{j}} \Delta \mathrm{S}_{\mathrm{t}-\mathrm{k}}+\mu_{\mathrm{t}}
$$

Model C

$$
\Delta \mathrm{S}_{\mathrm{t}}=\eta+\beta \mathrm{S}_{\mathrm{t}-1}+\beta_{\mathrm{t}}+\varphi \mathrm{DU}_{\mathrm{t}}+\lambda \mathrm{DT}_{\mathrm{t}}^{*}+\sum_{\mathrm{k}=1}^{\mathrm{h}} \mathrm{b}_{\mathrm{j}} \Delta \mathrm{S}_{\mathrm{t}-\mathrm{k}}+\mu_{\mathrm{t}}
$$

While $\mathrm{DU}_{\mathrm{t}}=1$ denotes the intercept dummy, $t$ is greater than the $\mathrm{T}_{\mathrm{B}}$ or may be zero (Time Break $\mathrm{T}_{\mathrm{B}}$ ) and the $\mathrm{DT}_{\mathrm{t}}^{*}=\mathrm{t}-\mathrm{T}_{\mathrm{B}}$, if $\mathrm{t}>\mathrm{T}_{\mathrm{B}}$ or zero. Here the important thing in the model A \& $\mathrm{C}$ is the hypothesis which states the stationery of the data has been tested. That's why Zivot and Andrew (1992) measured every point of a possible break in the data. 
The next step is to find the suiTable number of lags that how much past value of the variable will be beneficial for the work because the increase in the number of lags will weak the results of the study. Sims (1986) elaborates the importance of the lag taken in the model to capture the true picture of the economy. For this purpose, lag length criteria are employed, in which AIC selection criteria is preferred which explains the goodness fit of the model as well.

$$
\mathrm{A}_{\mathrm{t}}=\beta_{1} \mathrm{~A}_{\mathrm{t}-1}+\beta_{1} \mathrm{~A}_{\mathrm{t}-2}+\beta_{1} \mathrm{~A}_{\mathrm{t}-3} \ldots \ldots \ldots . \beta_{1} \mathrm{~A}_{\mathrm{t}-\mathrm{n}}+\mu_{\mathrm{t}}
$$

However, for the long-term affiliation among the factors Johansen Cointegration test (1991) is the suiTable techniques which have two segments such as.

$$
\begin{gathered}
\mathrm{J}_{\text {Trac }}(\mathrm{h})=-\mathrm{N} \underset{\mathrm{i}-\mathrm{m}+1}{\beta} \ln \left(1-\gamma_{\mathrm{i}}\right) \\
\mathrm{J}_{\text {Max }-\mathrm{Ei}}(\mathrm{h}+1)=-\mathrm{N} \ln \left(1-\gamma_{\mathrm{n}+1}\right)
\end{gathered}
$$

Although the ARDL is designed by the Pesaran et al (2001) which is independent of the order of the variables to investigate the co-integration among the Carbon emissions, gdppc, energy consumption, international trade, urbanization and the overall globalization. The Equation of the ARDL framework is as follows.

$$
\begin{aligned}
\Delta \ln C_{t} & =\beta_{0}+\sum_{j=1}^{h} \beta_{1 j} \Delta \ln C_{t-j}+\sum_{j=1}^{h} \beta_{2 j} \Delta \operatorname{lnGDPPC} \operatorname{Cos}_{t-j}+\sum_{j=1}^{h} \beta_{3 j} \Delta \ln \left(\mathrm{GDP}_{t-j}\right)^{2}+\sum_{j=1}^{h} \beta_{4 j} \Delta \ln \operatorname{Eng}_{t-j} \\
& +\sum_{j=1}^{h} \beta_{5 j} \Delta \operatorname{lnFdeve}_{t-j}+\sum_{j=1}^{h} \beta_{6 j} \Delta \ln \operatorname{Trade}_{t-j}+\sum_{j=1}^{h} \beta_{7 j} \Delta \operatorname{lnUbz}_{t-j}+\sum_{j=1}^{h} \beta_{8 j} \Delta \operatorname{lnGliz}_{t-j}+ \\
& \delta_{1} \ln C_{t-1}+\delta_{2} \operatorname{lnGDPPC}_{t-1}+\delta_{3} \ln C G D P_{t-1}^{2}+\delta_{4} \operatorname{lnEng}_{t-1}+\delta_{5} \ln \operatorname{Trade}_{t-1}+\delta_{6} \operatorname{lnUbz}_{t-1} \\
& +\delta_{1} \operatorname{lnGliz}_{t-1}+\mu_{t}
\end{aligned}
$$

After establishing the long run affiliation there is need to estimate the error correction model (ECM), whom equation can be formulated such as.

$$
\begin{aligned}
\Delta \ln C_{t}= & \beta_{0}+\sum_{j=1}^{h} \beta_{1 j} \Delta \ln C_{t-j}+\sum_{j=1}^{h} \beta_{2 j} \Delta \ln \operatorname{GDPPC}_{t-j}+\sum_{j=1}^{h} \beta_{3 j} \Delta \ln \left(\mathrm{GDP}_{t-j}\right)^{2}+\sum_{j=1}^{h} \beta_{4 j} \Delta \ln E n g_{t-j} \\
& +\sum_{j=1}^{h} \beta_{5 j} \Delta \operatorname{lnFdeve} e_{t-j}+\sum_{j=1}^{h} \beta_{6 j} \Delta \operatorname{lnTrade} \operatorname{Tr}_{t-j}+\sum_{j=1}^{h} \beta_{7 j} \Delta \operatorname{lnUbz}_{t-j}+ \\
& \sum_{j=1}^{h} \beta_{8 j} \Delta \operatorname{lnGliz}_{t-j}+\theta E C T_{t-1}+\eta_{t}
\end{aligned}
$$

Here ECT stands for the short-term affiliation and also illustrates the speed of adjustments of the variables to attain long term equilibrium. To confirm the fitness of the model, diagnostic and the stability tests are employed.

Further, to explore the flexible and fluctuating influence of the all the said variables this study also employs the VAR model, which beautifully resolve the problem of the endogeneity and the exogeneity. VAR is utilized to extract the information hidden in the data. It can be expressed like.

$$
Y_{t}=c+V_{1} Y_{t-1}+\ldots+V_{p} Y_{t-p}+\eta_{t}
$$

\section{Results and Discussion}

For the basic overview of the data, the data are presented descriptively, so the factors which are comprised of the data from 1970 to 2017 are illustrated in the Table 1. The results explain that carbon emission is about 0.99 KT which is between the 1.52 (maxi) and the 0.20 (mini) and GDP, EC, FD, TO, Ubz and the overall globalization are 8.00, 6.91, 3.12, 3.46, 4.04 and 3.91 respectively. While Figure 1 demonstrates the episodic increase in data.

Table 1: Descriptive Analysis of the Variables 


\begin{tabular}{|c|c|c|c|c|c|c|c|c|}
\hline Variables & Mean & Median & Maximum & Minimum & Std.Dev & Skewness & Kurtosis & Jarq-Bera \\
\hline $\mathrm{CO}_{2}$ & 0.99 & 1.02 & 1.52 & 0.20 & 0.37 & -0.28 & 1.96 & 2.77 \\
\hline $\mathrm{GDP}$ & 8.00 & 7.96 & 9.43 & 6.12 & 0.94 & -0.02 & 2.04 & 1.82 \\
\hline $\mathrm{GDP}^{2}$ & 8.69 & 8.65 & 10.13 & 6.81 & 0.94 & -0.02 & 2.04 & 1.82 \\
\hline $\mathrm{EC}$ & 6.91 & 6.89 & 7.53 & 6.25 & 0.32 & -0.02 & 2.04 & 1.82 \\
\hline $\mathrm{FD}$ & 3.12 & 2.90 & 4.26 & 2.60 & 0.47 & 1.32 & 3.38 & 14.29 \\
\hline $\mathrm{TO}$ & 3.46 & 3.60 & 4.00 & 2.20 & 0.51 & -0.93 & 2.58 & 7.35 \\
\hline $\mathrm{URB}$ & 4.04 & 4.11 & 4.31 & 3.64 & 0.21 & -0.53 & 1.84 & 4.97 \\
\hline Glob & 3.91 & 4.03 & 4.26 & 3.44 & 0.31 & -0.31 & 1.44 & 5.60 \\
\hline
\end{tabular}

CO2(meiri in per capion)
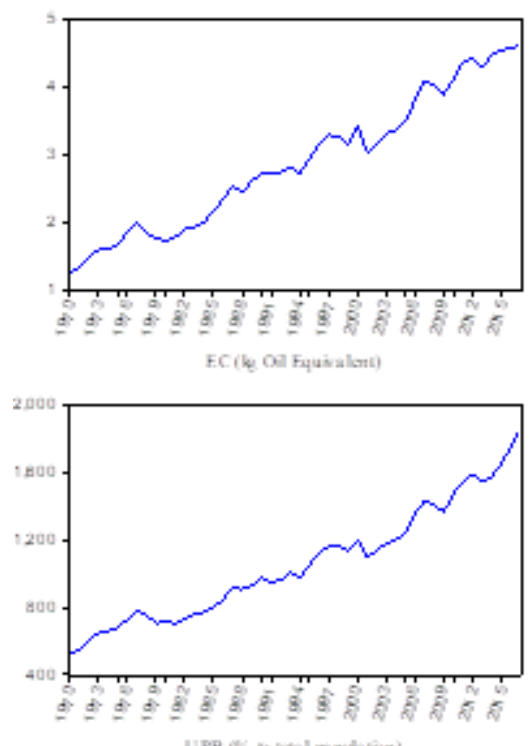

URA RS v usal papulation!

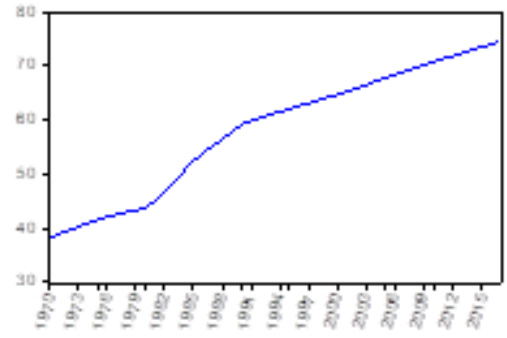

GPPPCiper cipia)
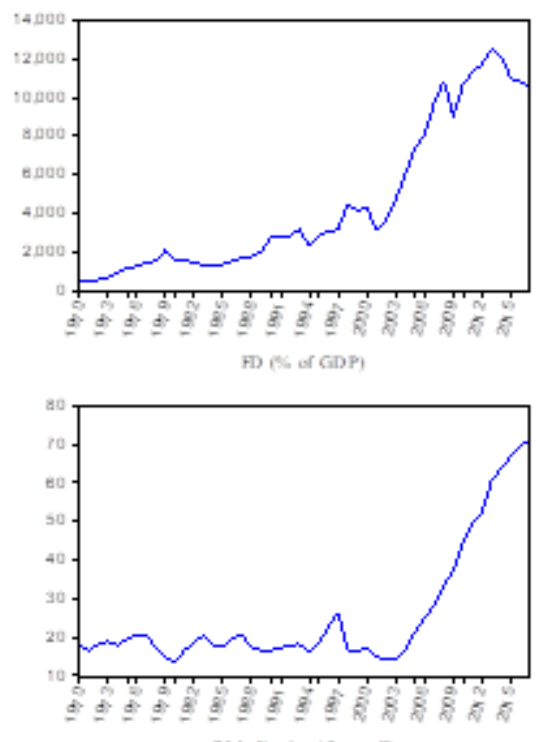

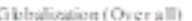

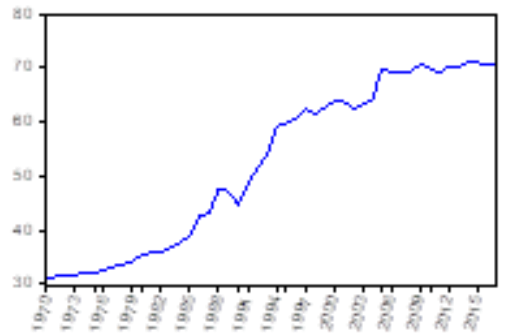

Figure 1: Trend of Variables

First of all, the study will find out the stationery while employing the unit root test, for this purpose each series were examined with the help of ADF and the PP tests. The results are shown in the Table 2 and Table 3.

Table 2: ADF Test Results

\begin{tabular}{llcccc}
\hline Variables & & t stat & $P$ value & Lag & Conclusion \\
\hline $\mathrm{Ln} \mathrm{CO}_{2}$ & Constant & -1.90 & 0.32 & 1 & \\
& $1^{\text {st }}$ Difference & -6.41 & $0.00^{*}$ & 1 & $\mathrm{I}(1)$ \\
& Trend and Constant & -3.31 & $0.07 * * *$ & 1 & $\mathrm{I}(\mathrm{I})$ \\
Ln GDP & Constant & -1.43 & 0.55 & 1 & \\
& $1^{\text {st }}$ Difference & -6.82 & $0.00^{*}$ & 1 & 1 \\
& Trend and Constant & -2.42 & 0.36 & &
\end{tabular}




\begin{tabular}{|c|c|c|c|c|c|}
\hline Ln GDP 2 & $\begin{array}{l}\text { Constant } \\
1^{\text {st }} \text { Difference } \\
\text { Trend and Constant }\end{array}$ & $\begin{array}{l}-1.43 \\
-6.82 \\
-2.42\end{array}$ & $\begin{array}{l}0.55 \\
0.00^{*} \\
0.36\end{array}$ & $\begin{array}{l}1 \\
1 \\
1\end{array}$ & $\mathrm{I}(1)$ \\
\hline Ln Ec & $\begin{array}{l}\text { Constant } \\
1^{\text {st }} \text { Difference } \\
\text { Trend and Constant }\end{array}$ & $\begin{array}{l}-0.66 \\
-6.22 \\
-3.92\end{array}$ & $\begin{array}{l}0.84 \\
0.00 * \\
0.01 *\end{array}$ & $\begin{array}{l}1 \\
1 \\
1\end{array}$ & $\mathrm{I}(1)$ \\
\hline Ln FD & $\begin{array}{l}\text { Constant } \\
1^{\text {st }} \text { Difference } \\
\text { Trend and Constant }\end{array}$ & $\begin{array}{l}-0.80 \\
-5.91 \\
-1.17\end{array}$ & $\begin{array}{l}0.94 \\
0.00 * \\
0.90\end{array}$ & $\begin{array}{l}1 \\
1 \\
1\end{array}$ & $\mathrm{I}(1)$ \\
\hline Ln TO & $\begin{array}{l}\text { Constant } \\
1^{\text {st }} \text { Difference } \\
\text { Trend and Constant }\end{array}$ & $\begin{array}{l}-1.93 \\
-5.90 \\
-2.54\end{array}$ & $\begin{array}{l}0.31 \\
0.00^{*} \\
0.30\end{array}$ & $\begin{array}{l}1 \\
1 \\
1\end{array}$ & $\mathrm{I}(1)$ \\
\hline Ln URB & $\begin{array}{l}\text { Constant } \\
1^{\text {st }} \text { Difference } \\
\text { Trend and Constant }\end{array}$ & $\begin{array}{l}-1.64 \\
-6.54 \\
-2.05\end{array}$ & $\begin{array}{l}0.67 \\
0.03 * * \\
0.55\end{array}$ & $\begin{array}{l}1 \\
1 \\
1\end{array}$ & $\mathrm{I}(1)$ \\
\hline Ln Glob & $\begin{array}{l}\text { Constant } \\
1^{\text {st }} \text { Difference } \\
\text { Trend and Constant }\end{array}$ & $\begin{array}{l}-1.16 \\
-6.54 \\
-0.55\end{array}$ & $\begin{array}{l}0.67 \\
0.00 * \\
0.97\end{array}$ & $\begin{array}{l}1 \\
1 \\
1\end{array}$ & $\mathrm{I}(1)$ \\
\hline
\end{tabular}

***,**\&*10,5\&1\% Significance level respectively

Table 3: Phillip Perron Test Results

\begin{tabular}{|c|c|c|c|c|c|}
\hline \multicolumn{2}{|l|}{ Variables } & \multirow{2}{*}{$\begin{array}{l}\text { t-stat } \\
-1.97\end{array}$} & \multirow{2}{*}{$\begin{array}{c}P \text { value } \\
0.29\end{array}$} & \multirow{2}{*}{$\begin{array}{c}\mathrm{Lag} \\
1\end{array}$} & \multirow[t]{2}{*}{ Conclusion } \\
\hline$\overline{\mathrm{Ln} \mathrm{CO}_{2}}$ & Constant & & & & \\
\hline & $1^{\text {st }}$ Difference & -6.52 & $0.00 *$ & 1 & $\mathrm{I}(1)$ \\
\hline & Trend and Constant & -3.37 & 0.26 & 1 & \\
\hline \multirow[t]{3}{*}{ Ln GDP } & Constant & -1.43 & 0.55 & 1 & $\mathrm{I}(\mathrm{I})$ \\
\hline & $1^{\text {st }}$ Difference & -6.83 & $0.00 *$ & 1 & \\
\hline & Trend and Constant & -2.59 & 0.30 & 1 & \\
\hline \multirow[t]{3}{*}{$\mathrm{Ln} \mathrm{GDP}^{2}$} & Constant & -1.43 & 0.55 & 1 & \\
\hline & $1^{\text {st }}$ Difference & -6.83 & $0.00 *$ & 1 & $\mathrm{I}(1)$ \\
\hline & Trend and Constant & -2.59 & 0.30 & 1 & \\
\hline \multirow[t]{3}{*}{ Ln Ec } & Constant & -0.66 & 0.84 & 1 & \\
\hline & $1^{\text {st }}$ Difference & -6.19 & $0.00 *$ & 1 & $\mathrm{I}(1)$ \\
\hline & Trend and Constant & -3.36 & 0.12 & 1 & \\
\hline \multirow[t]{3}{*}{ Ln FD } & Constant & -0.40 & 0.98 & 1 & \\
\hline & $1^{\text {st }}$ Difference & -5.20 & $0.00^{*}$ & 1 & $\mathrm{I}(1)$ \\
\hline & Trend and Constant & -0.92 & 0.94 & 1 & \\
\hline \multirow[t]{3}{*}{ Ln TO } & Constant & -1.93 & 0.31 & 1 & \\
\hline & $1^{\text {st }}$ Difference & -5.97 & $0.00^{*}$ & 1 & $\mathrm{I}(1)$ \\
\hline & Trend and Constant & -2.31 & 0.41 & 1 & \\
\hline \multirow[t]{3}{*}{ Ln Urb } & Constant & -2.22 & 0.20 & 1 & \\
\hline & $1^{\text {st }}$ Difference & -1.73 & $0.08 * * *$ & 1 & $\mathrm{I}(1)$ \\
\hline & Trend and Constant & -0.65 & 0.97 & 1 & \\
\hline
\end{tabular}




\begin{tabular}{llllll} 
Ln Glob & Constant & -1.14 & 0.68 & 1 & $\mathrm{I}(1)$ \\
& $1^{\text {st }}$ Difference & -6.56 & $0.00^{*}$ & 1 & \\
& Trend and Constant & -0.69 & 0.96 & 1 & \\
\hline$* * *, * * \& * 10,5 \& 1 \%$ Significance Level respectively & &
\end{tabular}

As mentioned from the Table 2 and Table 3, all the factors are non-stationery at the constant, although each and every factor becomes stationary at the 1 st difference. That's why this research rejected the H1: Non-stationery with a significance level of $1 \%$ and $5 \%$. It is advised from the results that all the series are stationary at the 1st difference. However, to find out the structural break in the data the study will employ the Zivot-Andrew (2002) unit root test, the results are presented in the Table 4.

Table 4: Structural Breaks Zivot Andrew Test

\begin{tabular}{|l|c|c|c|c|c|c|c|c|c|}
\hline \multirow{2}{*}{ Variables } & \multicolumn{3}{|c|}{ A-Intercept } & \multicolumn{4}{c|}{ B-Trend } & \multicolumn{3}{c|}{ Both = A \& B } \\
\cline { 2 - 10 } & t-Stat & Prob & Year & t-Stat & Prob & Year & t-Stat & Prob & Year \\
\hline Ln CO $_{2}$ & $-4.57^{*}$ & 0.00 & 1985 & -3.56 & 0.07 & 1997 & -4.33 & 0.01 & 1985 \\
\hline Ln GDP & -3.02 & 0.01 & 2003 & -2.48 & 0.33 & 1988 & -3.88 & 0.01 & 1980 \\
\hline Ln GDP & -3.02 & 0.01 & 2003 & -2.48 & 0.33 & 1988 & -3.88 & 0.01 & 1980 \\
\hline Ln EC & -4.39 & 0.60 & 1979 & -4.21 & 0.31 & 2006 & $-4.93 *$ & 0.00 & 2001 \\
\hline Ln FD & -3.12 & 0.01 & 2008 & $-5.11^{* * *}$ & 0.00 & 2004 & $-5.69^{* * *}$ & 0.00 & 2001 \\
\hline Ln TO & $-5.34 * * *$ & 9.1 & 1980 & -3.90 & 0.00 & 1988 & $-6.69^{* * *}$ & 5.73 & 1980 \\
\hline Ln Ubz & $-15.9 * * *$ & 2.5 & 1981 & $-5.28^{* * *}$ & 0.00 & 1994 & $-15.7^{* * *}$ & 1.32 & 1981 \\
\hline Ln Gliz & -2.63 & 0.00 & 1986 & -3.20 & 0.00 & 1998 & -3.93 & 0.00 & 1991 \\
\hline
\end{tabular}

$*, * *, * * *$, are the greater values from the critical vales.

The results shown that Carbon emission has the structural break (Intercept) in the year 1985 and electric consumption has the data break (A\&B) in the 2001, fiscal development has the data break (B-Trend) in 2004 and also has a break (if both $\mathrm{A} \& \mathrm{~B}$ is consider) at 2001 and trade openness has the structural break in the data in the year 1980 at (A-Intercept and Both= A\&B). Moreover, urbanization has the data break in all three categories B-Trend is at the 1994 while rest of two has the same year structural data break 1981.

The next important thing is the number of the past values of the factors, meaning that how much lags will be beneficial for the research. For this purpose, lag length was applied which is presented in the Table 5.

Table 5: Lag length Criteria

\begin{tabular}{|c|c|c|c|c|c|c|}
\hline Lag & LogL & LR & FPE & AIC & SC & HQ \\
\hline 0 & 265.80 & NA & $3.86 \mathrm{e}+14$ & -11.02 & -10.74 & 10.91 \\
\hline 1 & 650.17 & $637.56^{*}$ & $2.52 \mathrm{e}+20^{*}$ & $-25.28^{*}$ & $23.07^{*}$ & $24.45^{*}$ \\
\hline
\end{tabular}

The result of the lag length states that (AIC criteria) one lag will be suiTable for the work. Once knowing about the stationery of the data, the next techniques for long term affiliation named Johansen co-integration test was implemented. In the presence of the stochastic trends, this work employed the Johansen (1988) strategy for more than one equation to investigate the true long -term affiliation. Besides to detect the cumulative progress of all the factors in the model, presence of numerous sTable relations would be essential. Because the model is comprising on more than one variable so this study has expected more than one co-integrated vectors. For instance, if $n$ number of variables are then it can be (n-1) cointegration vectors. The outcomes of the Johansen Trace and Maxi-Eigen are presented in the Table 6 and Table 7.

Table 6: Trace Values

\begin{tabular}{|c|c|c|c|c|c|c|}
\hline $\begin{array}{c}\text { Null } \\
\text { Hypothesis }\end{array}$ & $\begin{array}{c}\text { Alternative } \\
\text { Hypothesis }\end{array}$ & Eigenvalue & $\begin{array}{c}\text { Trace } \\
\text { Statistic }\end{array}$ & 5\% Critical Value & Prob.** & $\begin{array}{c}\text { Hypothesized } \\
\text { No. of CE(s) }\end{array}$ \\
\hline $\mathrm{N}_{0}: \mathrm{j}=0$ & $\mathrm{~N}_{1}: \mathrm{j} \leq 1$ & 0.65 & 161.22 & 125.61 & 0.00 & None * \\
\hline $\mathrm{N}_{1}: \mathrm{j} \leq 1$ & $\mathrm{~N}_{1}: \mathrm{j} \leq 2$ & 0.56 & 112.89 & 95.75 & 0.00 & At most $1^{*}$ \\
\hline $\mathrm{N}_{1}: \mathrm{j} \leq 2$ & $\mathrm{~N}_{1}: \mathrm{j} \leq 3$ & 0.46 & 74.66 & 69.81 & 0.01 & At most $2^{*}$ \\
\hline $\mathrm{N}_{1}: \mathrm{j} \leq 3$ & $\mathrm{~N}_{1}: \mathrm{j} \leq 4$ & 0.41 & 45.87 & 47.85 & 0.07 & At most 3 \\
\hline
\end{tabular}


First two columns in the Table 06 shown the null hypothesis along with the alternative hypothesis. The result depicts that three-co-integrated equation are present because their relative trace statics are greater than the $5 \%$ critical value. While the results of the Max-Eigen results are demonstrated in the Table 7.

Table 7: Max-Eigen Values

\begin{tabular}{|c|c|c|c|c|c|c|}
\hline $\begin{array}{c}\text { Null } \\
\text { Hypothesis }\end{array}$ & $\begin{array}{c}\text { Alternative } \\
\text { Hypothesis }\end{array}$ & Eigenvalue & $\begin{array}{c}\text { Max-Eigen } \\
\text { Statistic }\end{array}$ & 5\% Critical Value & Prob.** & $\begin{array}{c}\text { Hypothesized } \\
\text { No. of CE(s) }\end{array}$ \\
\hline $\mathrm{H} 0: \mathrm{k}=0$ & $\mathrm{H} 1: \mathrm{k} \leq 1$ & 0.65 & 48.33 & 46.23 & 0.03 & None * \\
\hline $\mathrm{H} 1: \mathrm{k} \leq 1$ & $\mathrm{H} 1: \mathrm{k} \leq 2$ & 0.56 & 42.65 & 39.56 & 0.01 & At most $1^{*}$ \\
\hline $\mathrm{H} 1: \mathrm{k} \leq 2$ & $\mathrm{H} 1: \mathrm{k} \leq 3$ & 0.46 & 39.32 & 32.36 & 0.12 & At most $2^{*}$ \\
\hline $\mathrm{H} 1 \mathrm{k} \leq 3$ & $\mathrm{H} 1: \mathrm{k} \leq 4$ & 0.41 & 28.02 & 30.12 & 0.07 & At most 3 \\
\hline
\end{tabular}

Likewise, in the Table 7 Max-Eigen values are the greater than the 5\% critical values in the three cointegration equation meaning that there are three cointegration equation are present. So, this test confirms that all the factors are the incorporated in the long term and having the long-term affiliation with all other variables.

This study employs the ARDL bound test approach designed by the Pesaran et al. (2001) to investigate the short and the long-term association among the carbon emission, GDP, GDP2, electric consumption, fiscal development, trade openness, urbanization and the overall globalization. The pre-requisite for the ARDL is that no one would be stationery at 2nd difference. However the $\mathrm{H}_{0} \phi 0=\phi 1=\phi 2=\phi 3=\phi 4=\phi 5$ while $\mathrm{H}_{1}:\{\phi 0 \neq 0\} \mathrm{U}\{\phi 1 \neq$ $0\} \mathrm{U}\{\phi 2 \neq 0\} \mathrm{U}\{\phi 3 \neq 0\} \mathrm{U}\{\phi 4 \neq 0\} \mathrm{U}\{\phi 5 \neq 0\}$ having long term association between carbon emission and its independent variables. The results of the ARDL bound test are presented in the Table 8 .

Table 8: Bound Testing Estimations

\begin{tabular}{|c|c|c|c|c|}
\hline Test Stat & Value & Sigif. & I(0) & I(1) \\
\hline F-stat & 4.81 & $10 \%$ & 1.99 & 2.94 \\
\hline K & 6 & $5 \%$ & 2.27 & 3.28 \\
\hline
\end{tabular}

The F-state value is the 4.81 which is greater than the upper bound critical values at $5 \%$ and $1 \%$ level of significant along with the $\mathrm{K}=6$. This suggest that $\mathrm{H} 0$ with no cointegration is rejected in contrast to the H1 with cointegration. So, it is determined that long run affiliation among the carbon emission and the possible determinants of its emission i.e. (GDP, GDP2, electric consumption, fiscal development, trade openness, urbanization and the overall globalization).

However, Table 9 demonstrate the short and the long-term elasticities of the ARDL approach.

Table 9: ARDL Short and long-term Estimation

\begin{tabular}{|c|c|c|c|c|}
\hline Variables & Coefficient & Std. Error & t- Stat & Prob. \\
\hline$\Delta$ Ln GDP & 0.11 & 0.07 & 2.07 & $0.02^{*}$ \\
\hline$\Delta$ Ln GDP & -0.69 & 0.11 & -2.65 & $0.01^{*}$ \\
\hline$\Delta$ Ln EC & 0.38 & 0.35 & 1.08 & $0.00^{*}$ \\
\hline$\Delta$ Ln FD & 0.00 & 0.06 & 0.06 & $0.03 * *$ \\
\hline$\Delta$ Ln TO & -0.20 & 0.08 & -2.49 & $0.01^{* *}$ \\
\hline$\Delta$ Ln URB & -2.91 & 1.91 & -1.52 & 0.006 \\
\hline$\Delta$ Ln Glob & 0.00 & 0.21 & & $0.06^{* *}$ \\
\hline ECT & -1.172 & & 2.68 & $0.00^{*}$ \\
\hline Ln GDP & 0.14 & 0.05 & -3.79 & $0.01^{* *}$ \\
\hline Ln GDP & -1.99 & 0.05 & -3.30 & $0.01 *$ \\
\hline Ln EC & -0.52 & 0.16 & 3.04 & $0.00^{*}$ \\
\hline Ln FD & 0.09 & 0.03 & 2.48 & $0.00^{* * *}$ \\
\hline Ln TO & 0.20 & 0.08 & 1.64 & $0.01^{* *}$ \\
\hline Ln URB & 0.44 & 0.27 & -0.64 & $0.03^{*}$ \\
\hline Ln Glob & -0.11 & 0.17 & & $0.07^{*}$ \\
\hline
\end{tabular}




\begin{tabular}{|c|c|}
\hline Adjusted $\mathrm{R}^{2}$ & 0.89 \\
\hline AIC & -3.45 \\
\hline HQC & -2.82 \\
\hline
\end{tabular}

The Table 9 demonstrate the ARDL short and the long-term elasticities, which shows that GDP and the GDP2 have the positive and the negative magnitude with the significant influence, which implies that EKC is prevailing in the Turkish economy. In simple words, at first carbon emission increases with an increase in the GDP and after some verge gdp declines in the short run. This result is in line with Tamazian et al. (2009) in BRIC, Jalil \& Feridun (2011) in China, Pao \& Tsai (2011) in BRIC, Shahbaz et al. (2013c) in Turkey, Saboori \& Sulaiman (2013) in ASEAN countries, Shahbaz et al. (2013d) in South Africa, Ozturk \& Acaravci (2013) in Turkey, Shahbaz et al.(2015) in India, Ali et al. (2015) in Pakistan, Kasman \& Duman (2015) in new EU members, Shahbaz et al. (2016).

The ECT term which is known as the error correction term, this term is significant at $1 \%$ with the negative magnitude, which implies that about $117 \%$ disequilibrium is adjusted every year and the model would become sTable in the long term. This Table also represents the long-run elasticities of the ARDL model which illiterates that GDP and the GDP2 have the positive and the negative signs and 1\% level of significance which is the green signal of the validation of the EKC hypothesis in the Turkish economy. Moreover, it also shows that increase in the GDP carbon emission increases and then decrease to some extent in the long term, remaining all the other factors unchanged. These results were also found by Liua et al. (2007), Song et al. (2008), Jalil \& Mahmud (2009), Diao et al. (2009), Brajer et al. (2011), Jayanthakumaran et al. (2012), and Du et al. (2012) in case of China. Shahbaz et al. (2012) in Pakistan; Tiwari et al. (2013) India; Shahbaz et al. (2013a, b, c) in Turkey, Romania, and Indonesia; and Shahbaz et al. (2014b, c) Bangladesh and Tunisia.

The estimations also illustrate that EKC holds in the Turkish economy, electric consumption was determined significantly but negatively effect on $\mathrm{CO} 2$ emission. Although Fiscal development and the trade openness positively and significantly contributed to carbon emission. Consequently, Fiscal development and the trade openness in the Turkey are not environmentally friendly. The results concerning with the urbanization is interesting in Turkey, urbanization positively but insignificantly deteriorating the environment. While globalization has negative but insignificant affiliation with the carbon emission. Therefore, globalization does not aggravate environmental degradation.

In order to detect the stability and reliability of the ARDL model we apply diagnostic tests. The results of the diagnostic tests are represented in the Table 10. The autoregressive conditional heteroskedasticity (ARCH) (Engle, 1982) and Breusch-Godfrey serial correlation LM (Breusch, 1978; Godfrey, 1978) tests determine that results are free from the problems of heteroscedasticity and serial correlation as in both cases, because the probability value is greater than 0.05 . Here, the H0: homoscedasticity and no serial correlation are accepted. The Ramsey RESET test (Ramsey 1969) confirmed the correct model specification because the $\mathrm{p}$ value is greater than the 0.05 . However, the Jarque and Bera (1987) test was employed to detect the normality of the residual term. The H0: Normal distribution was accepted as the $\mathrm{p}$ value is greater than 0.05. Figures 3 and 4 show the CUSUM and the CUSUMSQ tests of parameter stability, respectively. The straight line represents critical bound at 5\% significance level. The null hypothesis of sTable parameters is accepted against the alternative hypothesis of unsTable parameters as the plots of CUSUM and CUSUMSQ statistic fall within the 5\% significance level Figure 3. This confirms that the short-run and long-run parameters of the ARDL model are stable and reliable.

Table 10: Results of diagnostic tests

Diagnostic tests

\begin{tabular}{llll}
\hline ARCH test & $\chi^{2}$-stat & $d f(1)$ & Probability (0.12) \\
Breusch-Godfrey serial & $\chi^{2}$-stat & $d f(1)$ & Probability (0.83) \\
Corelation LM test & & & \\
Ramsey RESET test & F-stat (16.2) & $d f(1,39)$ & Probability (0.23) \\
Jarque-Bera test & F-stat $(1.24)$ & & Probability (0.77) \\
\hline
\end{tabular}




\section{The Plot of Cumulative Sum of Recursive Residuals}

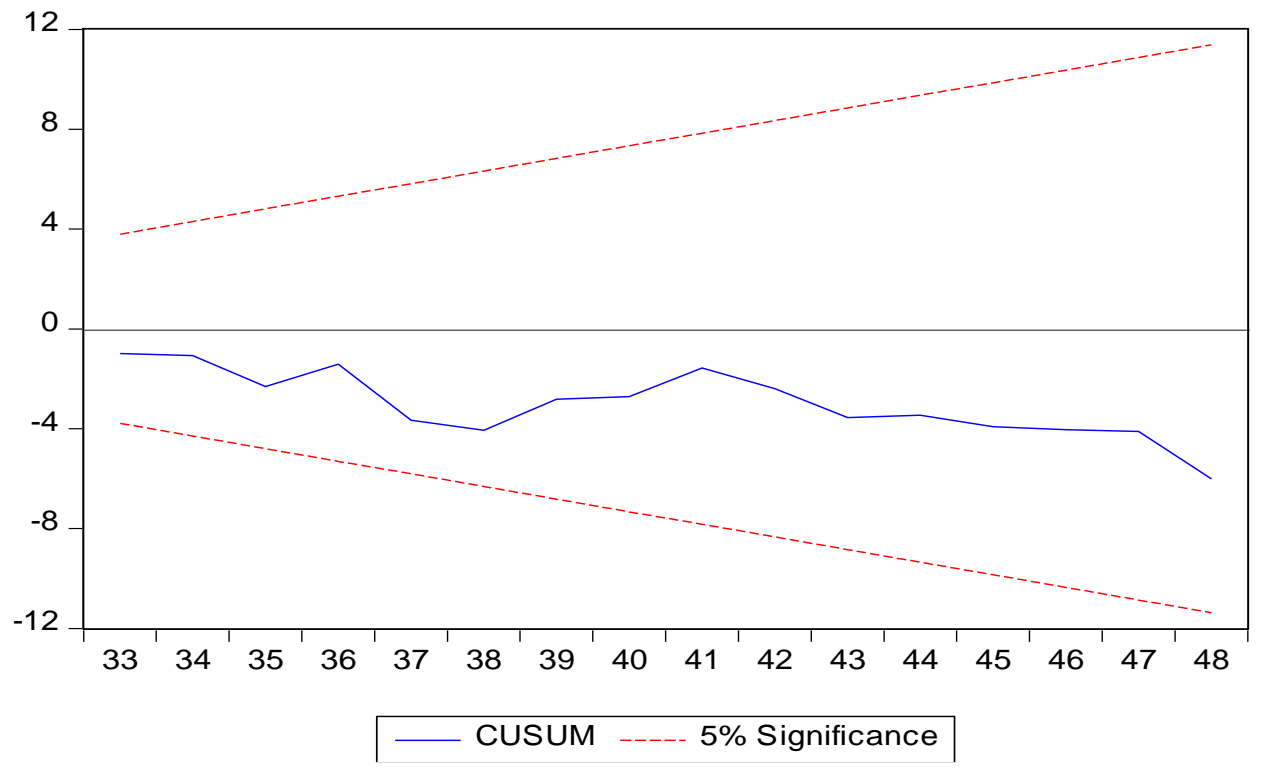

Figure 2: CUSUM test

\section{The Plot of Cumulative Sum of Squares of Recursive Residuals}

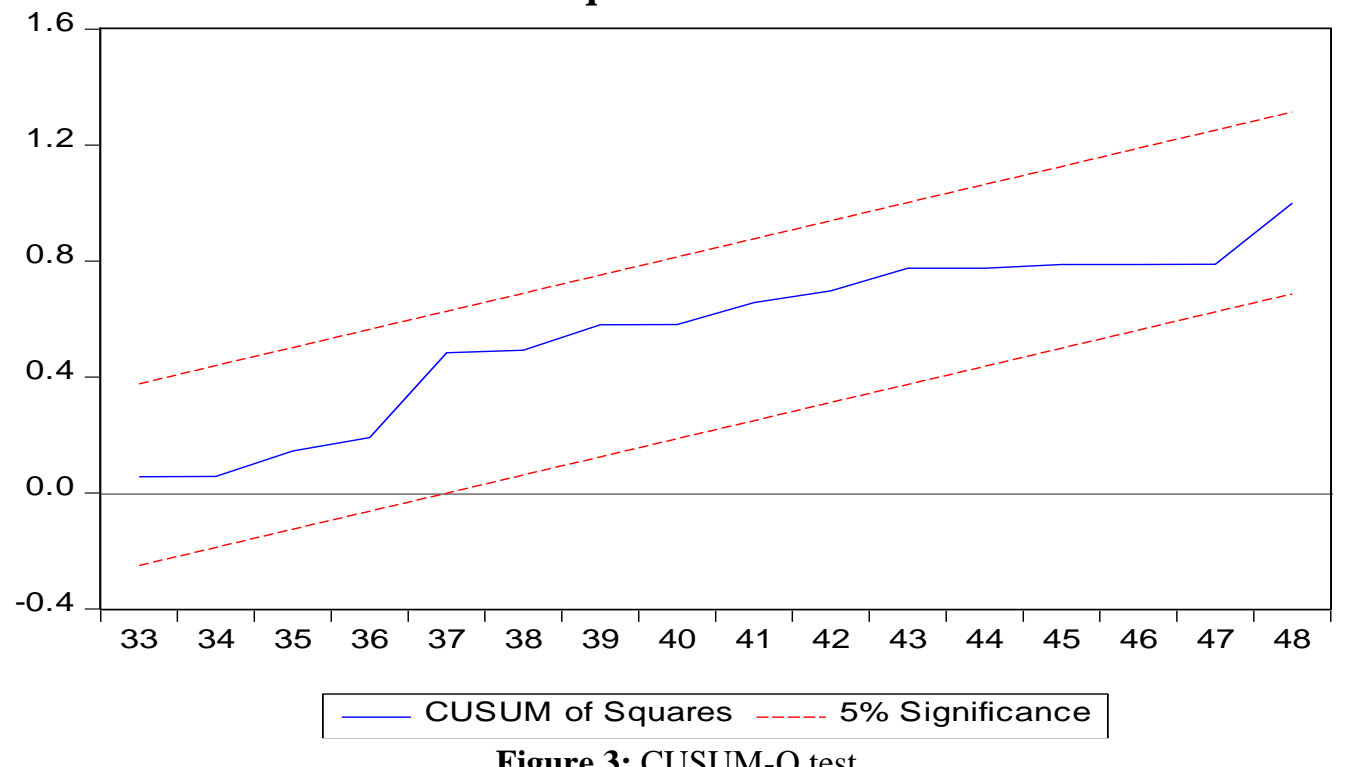

Moreover, we performed the Vector Auto- Regressive (VAR) model to investigate the linear dependency of multiple time series designed by the Sims (1980). This technique deals all the variables on the same line, independent of endogenous and the exogenous. This technique used by the policy makers for the experiment to change the behavior of the variable and also extract the information hidden in the data. The results are expressed in the Table 11.

Table 11: Results of diagnostic tests

\begin{tabular}{|c|c|c|c|c|c|c|c|}
\hline Variables & Ln CO 2 & Ln GDP & Ln EC & Ln FD & Ln TO & Ln Urb & Ln Glob \\
\hline & -0.03 & -1.30 & -0.44 & -1.27 & -0.97 & -0.02 & -0.11 \\
& $(0.32)$ & $(1.37)$ & $(0.26)$ & $(1.05)$ & $(1.01)$ & $(0.02)$ & $(0.25)$ \\
$\mathrm{Ln} \mathrm{CO}_{2}$ & {$[-0.09]$} & {$[-0.94]$} & {$[-1.64]$} & {$[-1.20]$} & {$[-0.95]$} & {$[-1.05]$} & {$[-0.46]$} \\
\hline
\end{tabular}


The p-values was 0.01 significant at $5 \%$ level which explains the long-term association among the factors, however to elaborates the results of the Table 11, we employ the Block Exogeneity test, which is presented in the Table 12.

Table 12: Results of diagnostic tests

\begin{tabular}{|c|c|c|c|}
\hline \multicolumn{5}{|c|}{ Dependent Variable: Ln CO } \\
\hline Excluded & Chi-sq & df & Prob. \\
\hline Ln GDP & 5.871 & 2 & 0.05 \\
\hline Ln EC & 1.074 & 2 & 0.42 \\
\hline Ln FD & 6.416 & 2 & 0.04 \\
\hline Ln TO & 10.29 & 2 & 0.00 \\
\hline Ln Urb & 9.961 & 2 & 0.00 \\
\hline Ln Glob & 0.452 & 2 & 0.79 \\
\hline All & 47.048 & 2 & 0.00 \\
\hline
\end{tabular}

The result illiterates that gross domestic per capita, fiscal development, trade openness and urbanization have strong influence on the carbon emission in the economy, consequently the cumulative influence of all the possible determinants of the carbon emission in the Turkish economy are cause the environment degradation.

Therefore, we also apply the impulse response function to elaborate the dynamic/ fluctuating behavior of the variables. The impulse response function shows that when shock of a variables is given to the all other variables in the system then how and in what direction factors moves i.e. its respond positively or the negatively.

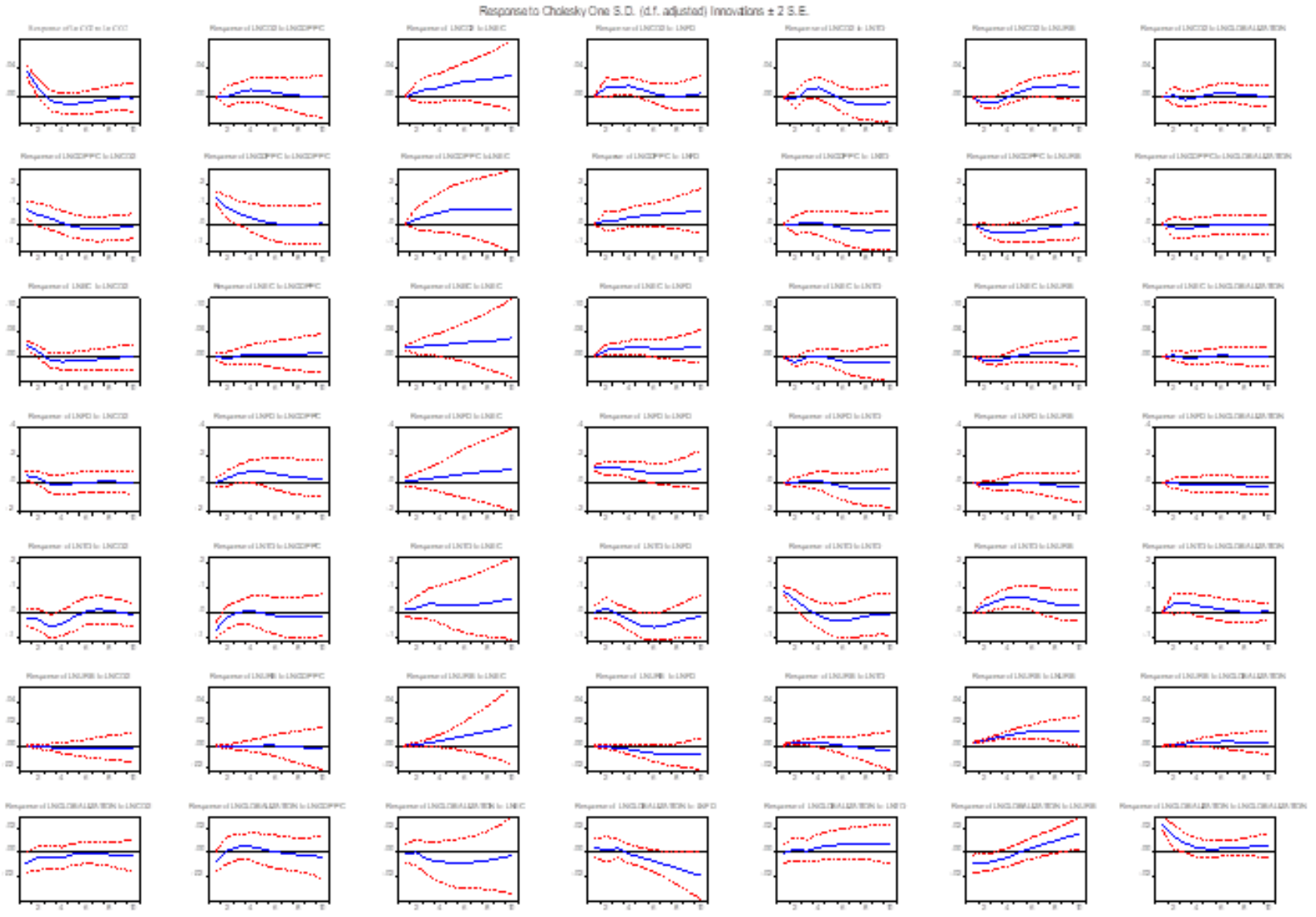

Figure 4: Impulse Response Function

The figure illustrates that when a standard deviation shock of GDP per capita is given to the carbon emission, then the response of the carbon emission would be positive. It will increase with the increasing rate after that moves towards the equilibrium line. Simply can say that increase in the GDP per capita will lead to increase the carbon emission. 
The deviation shock state that an increase in the electric consumption would also increase the carbon emission with the increasing rate. The rate of increase as compared to the GDP per capita is higher and with the passage of time the gap between increasing rate and the equilibrium line is widening. Meaning that the carbon emission caused by the electric consumption is greater than the carbon emitted by the GDP per capita.

With an increase in the fiscal development the carbon emission would increase to its high level and then starts to fall towards equilibrium line, and finally attain the stability. However, the carbon emission generated by the fiscal development is almost alike carbon emission by the GDP per capita. But the CO2 emission caused by the electric consumption is higher than the carbon emission by the fiscal development.

In the case of the trade openness, when the standard shock of trade openness is given to the carbon dioxide then initially, it responds negatively but with increase in the trade it will starts to increase. After achieving the peak level then start to decline, and becomes negative. In other words, initially with an increase in the trade openness, carbon emission also increases to a specific level. After that carbon emission decreases with an increase in the level of trade openness. However, the carbon emission caused by the trade is less as compared to the carbon emission caused by the GDP per capita, electric consumption and the fiscal development.

When a standard deviation shock of urbanization is given to the carbon emission, the figure elaborates that initially the carbon emission does down with an increase in the level of urbanization but with the passage of time its increases with an increasing rate and then moves parallel to the equilibrium line. The impulse response reveals that the carbon emission increase with an increase in the urbanization, but low rate as compared to the GDP per capita, electric consumption, fiscal development and as well as the trade openness.

In the case of globalization, the IRF determines that due to increase in the globalization the carbon emission will approximately remain on the equilibrium line. The response of $\mathrm{CO} 2$ emission in the case of globalization is totally different from all the other variables included in the study.

\section{Conclusion and Suggestions}

In this study, an effort was made to analysis the association between carbon emission and its expected determinants. And this study also investigates and confirm the EKC hypothesis in the presence of the GDP per capita, electric consumption, fiscal development, trade openness, urbanization and the overall globalization in the case of Turkey. For this purpose, the study employs the time series data comprises on the 1970 to 2017. The study used the Johansen co-integration, ARDL, Block Exogeneity and Impulse response function to analyze the long-term affiliation and the strength of the association among carbon emission and possible determinants. To accomplish the cointegration, ARDL Block Exogeneity and Impulse Response Function, initially study detect the stationery with the assistance of the ADF, PP and ZA unit root test. The ADF and PP confirms that all the variables are integrated of order one and ZA determines the structural break in the data with different years. The Johansen and ARDL approach approve that carbon emission and its possible factors are cointegrated in the long term. Moreover, the results of the ARDL reveals that inverted U-shape affiliation exists between carbon emission and its possible determinants both in the short and the long term. Therefore, the study confirms the expected carbon emission determinants and economic growth positively and significantly participate to environmental depletion in Turkey.

Under the consideration of the results, the final statements and policy suggestion appears. Based on the finding of the study. Indeed, the estimations represents that all the expected possible factors (CO2, GDP per capita, electric consumption, fiscal development, trade openness, urbanization and the overall globalization) has a vigorous affiliation with environmental depletion in Turkey. To avoid the environmental degradation, it is suggested that the national policy regarding environmental safety should be reformed and implemented strictly. To support the environment friendly rules and regulations should be formulated through a better democracy. It would stimulate the independency of information circulation and political freedom. Consequently, it would smooth the way for legislation for environment and promotes the public awareness. Definitely, increase in the public awareness also promotes the environmental quality. In concluding remarks the study suggests that the government should embrace the stabilization growth policy in the economy. 


\section{Reference}

Abas, N., \& Khan, N. (2014). Carbon conundrum, climate change, CO2 capture and consumptions. Journal of $\mathrm{CO}_{2}$ Utilization, 8, 39-48.

Ahmed, K., Shahbaz, M., Qasim, A., \& Long, W. (2015). The linkages between deforestation, energy and growth for environmental degradation in Pakistan. Ecological Indicators, 49, 95-103.

Ahmed, K., Rehman, M. U., \& Ozturk, I. (2017). What drives carbon dioxide emissions in the long-run? Evidence from selected South Asian Countries. Renewable and Sustainable Energy Reviews, 70, 1142-1153.

Alam, S., Fatima, A., \& Butt, M. S. (2007). Sustainable development in Pakistan in the context of energy consumption demand and environmental degradation. Journal of Asian Economics, 18(5), 825-837.

Ali, H. S., Law, S. H., Lin, W. L., Yusop, Z., Chin, L., \& Bare, U. A. A. (2019). Financial development and carbon dioxide emissions in Nigeria: evidence from the ARDL bounds approach. Geo Journal, 84(3), 641-655.

Al-mulali, U., \& Normee Che Sab, C. (2013). Energy consumption, pollution and economic development in 16 emerging countries. Journal of Economic Studies, 40(5), 686-698.

Al-Mulali, U., Tang, C.F., \& Ozturk, I. (2015). Estimating the environment Kuznets curve hypothesis: evidence from Latin America and the Caribbean countries. Renew Sustainable Energy, 50, 918-924.

Al-Mulali, U., Ozturk, I., \& Lean, H. H. (2015). The influence of economic growth, urbanization, trade openness, financial development, and renewable energy on pollution in Europe. Natural Hazards, 79(1), 621-644.

Al-Mulali, U., Saboori, B., \& Ozturk, I. (2015). Investigating the environmental Kuznets curve hypothesis in Vietnam. Energy Policy, 76, 123-131.

Arouri, M. E. H., Youssef, A. B., M'henni, H., \& Rault, C. (2012). Energy consumption, economic growth and $\mathrm{CO}_{2}$ emissions in Middle East and North African countries. Energy policy, 45, 342-349.

Antweiler, W., Copeland, B. R., \& Taylor, M. S. (2001). Is free trade good for the environment? American Economic Review, 91(4), 877-908.

Apergis, N., \& Payne, J. E. (2009). $\mathrm{CO}_{2}$ emissions, energy usage, and output in Central America. Energy Policy, 37(8), 3282-3286.

Aung, T. S., Saboori, B., \& Rasoulinezhad, E. (2017). Economic growth and environmental pollution in Myanmar: an analysis of environmental Kuznets curve. Environmental Science and Pollution Research, 24(25), 2048720501.

Bombardini, M. \& Li, B. (2016). Trade, pollution and mortality in China. National Bureau of economic research. NBER Working Paper No. 22804.

Boutabba, M. A. (2014). The impact of financial development, income, energy and trade on carbon emissions: Evidence from the Indian economy. Economic Modelling, 40, 33-41.

Baek, J., \& Pride, D. (2014). On the income-nuclear energy-CO2 emissions nexus revisited. Energy Economics, 43, 6-10. 
Baranzini, A., Weber, S., Bareit, M., \& Mathys, N. A. (2013). The causal relationship between energy use and economic growth in Switzerland. Energy Economics, 36, 464-470.

Charfeddine, L., \& Khediri, K. B. (2016). Financial development and environmental quality in UAE: Cointegration with structural breaks. Renewable and Sustainable Energy Reviews, 55, 1322-1335.

Chen, S. T., Kuo, H. I., \& Chen, C. C. (2007). The relationship between GDP and electricity consumption in 10 Asian countries. Energy Policy, 35(4), 2611-2621.

Chen, L., Xu, L., \& Yang, Z. (2017). Accounting carbon emission changes under regional industrial transfer in an urban agglomeration in China's Pearl River Delta. Journal of Cleaner Production, 167, 110-119.

Copeland, B. R., \& Taylor, M. S. (1995). Trade and the environment: a partial synthesis. American Journal of Agricultural Economics, 77(3), 765-771.

Dasgupta, S., Laplante, B., \& Mamingi, N. (2001). Pollution and capital markets in developing countries. Journal of Environmental Economics and Management, 42(3), 310-335.

Dean, J. M. (2002). Testing the impact of trade liberalization on the environment: theory and evidence. Canadian Journal of Economics, 35, 819-842.

Dinda, S. (2004). Environmental Kuznets curve hypothesis: a survey. Ecological Economics, 49(4), 431-455.

Edwards, S. (1992). Trade orientation, distortions and growth in developing countries. Journal of Development Economics, 39(1), 31-57.

Farhani, S., \& Ozturk, I. (2015). Causal relationship between CO 2 emissions, real GDP, energy consumption, financial development, trade openness, and urbanization in Tunisia. Environmental Science and Pollution Research, 22(20), 15663-15676.

Farhani, S., Chaibi, A., \& Rault, C. (2014). CO2 emissions, output, energy consumption, and trade in Tunisia. Economic Modelling, 38, 426-434.

Han, J., Meng, X., Zhou, X., Yi, B., Liu, M., \& Xiang, W. N. (2017). A long-term analysis of urbanization process, landscape change, and carbon sources and sinks: A case study in China's Yangtze River Delta region. Journal of Cleaner Production, 141, 1040-1050.

He, L., Xu, J., Xu, Y. X., \& Li, H. X. (2013). Empirical study on the relationship between China's natural gas consumption demand and gas transmission network. Inquiry Into Economic Issues, 4, 70-73.

Heidari, H., Katircioğlu, S. T., \& Saeidpour, L. (2015). Economic growth, CO2 emissions, and energy consumption in the five ASEAN countries. International Journal of Electrical Power \& Energy Systems, 64, 785-791.

Hossain, M. S. (2011). Panel estimation for CO2 emissions, energy consumption, economic growth, trade openness and urbanization of newly industrialized countries. Energy Policy, 39(11), 6991-6999.

Gholipour Fereidouni, H. (2013). Foreign direct investments in real estate sector and CO2 emission: Evidence from emerging economies. Management of Environmental Quality: An International Journal, 24(4), 463-476.

Frankel, J. A. (2009). Environmental effects of international trade. HKS Faculty Research Working Paper Series. 
Naradda Gamage, S. K., Hewa Kuruppuge, R., \& Haq, I. U. (2017). Energy consumption, tourism development, and environmental degradation in Sri Lanka. Energy Sources, Part B: Economics, Planning, and Policy, 12(10), 910-916.

Gill, A. R., Viswanathan, K. K., \& Hassan, S. (2018). The Environmental Kuznets Curve (EKC) and the environmental problem of the day. Renewable and Sustainable Energy Reviews, 81, 1636-1642.

Grossman, G. M., \& Krueger, A. B. (1991). Environmental impacts of a North American free trade agreement (No. w3914). National Bureau of Economic Research.

Ghosh, S. (2010). Examining carbon emissions economic growth nexus for India: a multivariate cointegration approach. Energy Policy, 38(6), 3008-3014.

IEA. (2016). CO2 emissions from fuel combustion highlights (2016 edition). International Energy Agency, Paris.

IRENA. (2016). Renewable energy in cities. IRENA, Abu Dhabi.

Javid, M., \& Sharif, F. (2016). Environmental Kuznets curve and financial development in Pakistan. Renewable and Sustainable Energy Reviews, 54, 406-414.

Kanjilal, K., \& Ghosh, S. (2013). Environmental Kuznet's curve for India: Evidence from tests for cointegration with unknown structural breaks. Energy Policy, 56, 509-515.

Karl, T. R., \& Trenberth, K. E. (2003). Modern global climate change. Science, 302(5651), 1719-1723.

Kijima, M., Nishide, K., \& Ohyama, A. (2010). Economic models for the environmental Kuznets curve: A survey. Journal of Economic Dynamics and Control, 34(7), 1187-1201.

Li, D., \& Yang, D. (2016). Does non-fossil energy usage lower CO2 emissions? Empirical evidence from China. Sustainability, 8(9), 874

Liddle, B. (2001). Free trade and the environment-development system. Ecological Economics, 39(1), 21-36.

Shahbaz, M., Khan, S., Ali, A., \& Bhattacharya, M. (2017). The impact of globalization on CO2 emissions in China. The Singapore Economic Review, 62(04), 929-957.

Ling, C. H., Ahmed, K., Muhamad, R. B., \& Shahbaz, M. (2015). Decomposing the trade-environment nexus for Malaysia: what do the technique, scale, composition, and comparative advantage effect indicate? Environmental Science and Pollution Research, 22(24), 20131-20142.

Marsiglio, S., Ansuategi, A., \& Gallastegui, M. C. (2016). The environmental Kuznets curve and the structural change hypothesis. Environmental and Resource Economics, 63(2), 265-288.

McAusland, C. (2008). Trade, politics, and the environment: Tailpipe vs. smokestack. Journal of Environmental Economics and Management, 55(1), 52-71.

NASA. July 25, 2015, from http://climate.nasa.gov/evidence

Nguyen, Q. A., Kakinaka, M., \& Kotani, K. (2017). How does urbanization affect energy and CO2 emission intensities in Vietnam? Evidence from province-level data. 
Nasir, M., \& Rehman, F. U. (2011). Environmental Kuznets curve for carbon emissions in Pakistan: an empirical investigation. Energy Policy, 39(3), 1857-1864.

OECD. World Energy Outlook, 2014.

Ozatac, N., Gokmenoglu, K. K., \& Taspinar, N. (2017). Testing the EKC hypothesis by considering trade openness, urbanization, and financial development: the case of Turkey. Environmental Science and Pollution Research, 24(20), 16690-16701.

Ozturk, I., \& Al-Mulali, U. (2015). Investigating the validity of the environmental Kuznets curve hypothesis in Cambodia. Ecological Indicators, 57, 324-330.

Pata, U. K. (2018). The effect of urbanization and industrialization on carbon emissions in Turkey: evidence from ARDL bounds testing procedure. Environmental Science and Pollution Research, 25(8), 7740-7747.

Pata, U. K. (2018). Renewable energy consumption, urbanization, financial development, income and CO2 emissions in Turkey: testing EKC hypothesis with structural breaks. Journal of Cleaner Production, 187, 770779.

Rafindadi, A. A. (2016). Revisiting the concept of environmental Kuznets curve in period of energy disaster and deteriorating income: Empirical evidence from Japan. Energy Policy, 94, 274-284.

Seker, F., Ertugrul, H. M., \& Cetin, M. (2015). The impact of foreign direct investment on environmental quality: a bounds testing and causality analysis for Turkey. Renewable and Sustainable Energy Reviews, 52, 347-356.

Sharma, S. S. (2011). Determinants of carbon dioxide emissions: empirical evidence from 69 countries. Applied Energy, 88(1), 376-382.

Shahbaz, M., Ozturk, I., Afza, T., \& Ali, A. (2013). Revisiting the environmental Kuznets curve in a global economy. Renewable and Sustainable Energy Reviews, 25, 494-502.

Shahbaz, M., \& Lean, H. H. (2012). The dynamics of electricity consumption and economic growth: A revisit study of their causality in Pakistan. Energy, 39(1), 146-153.

Shahbaz, M., Hye, Q. M. A., Tiwari, A. K., \& Leitão, N. C. (2013). Economic growth, energy consumption, financial development, international trade and $\mathrm{CO} 2$ emissions in Indonesia. Renewable and Sustainable Energy Reviews, 25, 109-121.

Shahbaz, M., Ozturk, I., Afza, T., \& Ali, A. (2013). Revisiting the environmental Kuznets curve in a global economy. Renewable and Sustainable Energy Reviews, 25, 494-502.

Shahbaz, M., Sbia, R., Hamdi, H., \& Ozturk, I. (2014). Economic growth, electricity consumption, urbanization and environmental degradation relationship in United Arab Emirates. Ecological Indicators, 45, 622-631.

Saboori, B., Sulaiman, J., \& Mohd, S. (2012). Economic growth and CO2 emissions in Malaysia: a cointegration analysis of the environmental Kuznets curve. Energy Policy, 51, 184-191.

Sadorsky, P. (2012). Energy consumption, output and trade in South America. Energy Economics, 34(2), 476-488.

Sinha, A., \& Bhatt, M. Y. (2017). Environmental Kuznets Curve for CO2and NOx emissions: A Case Study of India. European Journal of Sustainable Development, 6(1), 267-276. 
Sharma, S. S. (2011). Determinants of carbon dioxide emissions: empirical evidence from 69 countries. Applied Energy, 88(1), 376-382.

Tamazian, A., Chousa, J. P., \& Vadlamannati, K. C. (2009). Does higher economic and financial development lead to environmental degradation: evidence from BRIC countries. Energy Policy, 37(1), 246-253.

Clark-Bennett, R. (2004). Towards a Socially Sustainable World Economy: An Analysis of the Social Pillars of Globalization, and: Making Sweatshops: The Globalization of the US Apparel Industry. Labor Studies Journal, 29(2), 133-134.

Shahbaz, M., Khan, S., Ali, A., \& Bhattacharya, M. (2017). The impact of globalization on CO2 emissions in China. The Singapore Economic Review, 62(04), 929-957.

Ullah, A., Khan, D., Khan, I., \& Zheng, S. (2018). Does agricultural ecosystem cause environmental pollution in Pakistan? Promise and menace. Environmental Science and Pollution Research, 25(14), 13938-13955.

Wang, Y., Li, L., Kubota, J., Han, R., Zhu, X., \& Lu, G. (2016). Does urbanization lead to more carbon emission? Evidence from a panel of BRICS countries. Applied Energy, 168, 375-380.

Wolde-Rufael, Y. (2005). Energy demand and economic growth: the African experience. Journal of Policy Modeling, 27(8), 891-903.

Yandle, B., Bhattarai, M., \& Vijayaraghavan, M. (2004). Environmental Kuznets curves: a review of findings, methods, and policy implications.

Yuan, J., Zhao, C., Yu, S., \& Hu, Z. (2007). Electricity consumption and economic growth in China: cointegration and co-feature analysis. Energy Economics, 29(6), 1179-1191.

ZiabakhshGanji, Z. (2015). Physical and geochemical impacts of impure CO2 on storage in depleted hydrocarbon reservoirs and saline aquifers.

Zhang, B., Wang, Z., \& Wang, B. (2018). Energy production, economic growth and CO 2 emission: evidence from Pakistan. Natural Hazards, 90(1), 27-50.

Zhang, P., He, J., Hong, X., Zhang, W., Qin, C., Pang, B., \& Liu, Y. (2017). Regional-level carbon emissions modelling and scenario analysis: A STIRPAT case study in Henan province, China. Sustainability, 9(12), 2342.

Zhang, C., \& Lin, Y. (2012). Panel estimation for urbanization, energy consumption and CO2 emissions: A regional analysis in China. Energy Policy, 49, 488-498.

Zhang, S., Liu, X., \& Bae, J. (2017). Does trade openness affect CO 2 emissions: evidence from ten newly industrialized countries? Environmental Science and Pollution Research, 24(21), 17616-17625. 